\title{
Experimental investigation of passively cooled photovoltaic modules on the power output performance
}

\author{
Emy Zairah Ahmad ${ }^{1,2}$, Kamaruzzaman Sopian ${ }^{1}$, Adnan Ibrahim ${ }^{1}$, Chin Kim Gan ${ }^{3}$, \\ Mohd Suffian Ab Razak ${ }^{4}$ \\ ${ }^{1}$ Solar Energy Research Institute, Universiti Kebangsaan Malaysia, Bangi Selangor, Malaysia \\ ${ }^{2}$ Faculty of Electrical \& Electronic Engineering Technology, Universiti Teknikal Malaysia Melaka, Malaysia \\ ${ }^{3}$ CeRIA Faculty of Electrical Engineering, Universiti Teknikal Malaysia Melaka, Malaysia \\ ${ }^{4}$ Faculty of Mechanical and Manufacturing Engineering Technology, Universiti Teknikal Malaysia Melaka, Malaysia
}

\begin{abstract}
Article Info
Article history:

Received Sep 3, 2021

Revised Jan 19, 2022

Accepted Jan 26, 2022

Keywords:

Fins heat sink

Photovoltaic cooling

Power conversion efficiency

$\mathrm{PV}$ module temperature

PV performance

ABSTRACT

The power output performance of a photovoltaic (PV) module decreases as the temperature increases. The increase in module temperature above the standard test conditions $\left(25^{\circ} \mathrm{C}\right)$ could reduce the average power output by at least $0.2 \%$ for each $1{ }^{\circ} \mathrm{C}$ rise. Hence, keeping the module temperature low is necessary for PV systems exposed to high solar irradiance throughout the year. Therefore, this study aims to experimentally analyse the eletctrical performance of passively cooled PV modules in the tropics. The developed cooling approach consists of rectangular plate fins made of aluminum 6061, attached to the rear surface of tedlar layer. The results indicated that the average module temperature reduction of $3.25^{\circ} \mathrm{C}$ was observed under outdoor exposures. As a result, the heat sink improved the overall power output up to 14.2\%. As the PV performances are site-dependent, these findings are beneficial as it provides a thorough explanation of fin heat sink behavior under long-term field exposures of tropics.
\end{abstract}

This is an open access article under the CC BY-SA license.

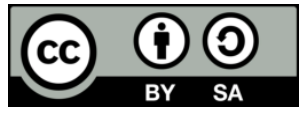

Corresponding Author:

Adnan Ibrahim

Solar Energy Research Institute, Universiti Kebangsaan Malaysia (UKM)

43600, Bangi Selangor, Malaysia

Email: iadnan@ukm.edu.my

\section{INTRODUCTION}

Solar energy has the potential to reduce the profound long-term threat of global carbon dioxide $\left(\mathrm{CO}_{2}\right)$ emissions. Research on alternative energy resources started to emerge, and evaluating each technology is necessary to support climate change policies and mitigation. The International Energy Agency (IEA) has recently reported that $27 \%$ of global energy generation in 2050 will be supplied by solar photovoltaic (PV). However, an in-depth research is required to enable the competitiveness of solar PV in the future energy market. Nevertheless, a silicon (Si) PV module technology absorbs $80 \%$ of incident solar irradiance, but only $20 \%$ is converted into useful energy [1]. The percentage of power reduction per degree celsius ranges typically from $0.2 \% /{ }^{\circ} \mathrm{C}$ to $0.5 \% /{ }^{\circ} \mathrm{C}$ and highly influences the decrease in voltage and power conversion efficiency (PCE) [2]. It has been a constant challenge for a PV system exposed to continuously high solar irradiance [3]. To overcome this limitation, keeping the module temperature low is necessary.

Various authors reported significant studies on different PV cooling methodologies, and it can be categories as passive and active cooling [4]. The primary concern of PV cooling is to eliminate excess heat in periods of high solar irradiance and over long field exposures. Despite various cooling techniques addressed in [5]-[11], passive cooling is more promising than active cooling. They require no auxiliary input power, and surrounding air naturally cools the PV modules. For instance, Johnston et al. [12] proposed a continuous 
rectangular fin profile of varying fin height to cool a solar cell of 0.8 Watt. Under indoor testing conditions, the fin height of 20 and $100 \mathrm{~mm}$ demonstrated an optimal relative power increment of $11.3 \%$ and $15.27 \%$, respectively. Similar studies were reported in [13], [14] with rectangular fin profiles tested using $250 \mathrm{Wp}$ poly$\mathrm{Si}$ modules. The authors concluded that, at $100 \mathrm{~mm}$ fin height, the effect of fin thickness is not noticeable. The proposed heat sinks have reduced the module temperature by $4{ }^{\circ} \mathrm{C}$, with an improvement of $3 \%$ in the overall power conversion efficiency. In addition, Elbreki et al. [15] proposed a novel lapping fin with planar reflectors and tested it using a $40 \mathrm{Wp}$ poly-Si module. The experimental results demonstrated that the lapping fin profiles outweigh the rectangular fin of similar fin height $(200 \mathrm{~mm})$ with a reduced temperature of $24.6^{\circ} \mathrm{C}$. The authors also reported that the module electrical efficiency with lapping fins with planar reflector increased $10.68 \%$.

Cabo et al. [16] conducted studies with randomly positioned perforated fins to reduce the module temperature. The proposed fins were tested on a $50 \mathrm{Wp}$ poly-Si module under outdoor testing conditions, and the fin height was maintained at $100 \mathrm{~mm}$. The experimental results showed a $2 \%$ relative increase in electrical efficiency. Arifin et al. [17] experimentally analyse the effect of using perforated fins on PV module temperature. The average module temperature with and without perforated heat sinks was recorded at $72.8{ }^{\circ} \mathrm{C}$ and $85.3{ }^{\circ} \mathrm{C}$, respectively. The overall maximum power was increased by $18.67 \%$. Bayrak et al. [18] studied module temperature using staggered vertical fins. The highest temperature reduction of $3.39^{\circ} \mathrm{C}$ was observed under the $772.83 \mathrm{~W} / \mathrm{m}^{2}$ solar irradiance, accounting for an $11.55 \%$ efficiency improvement. On the other hand, Perez et al. [19] proposed alternative fin geometries with an angled-discontinuous fin profile and improved the heat extraction. The experimental observations indicated that the temperature reduction was within the range of $5-7{ }^{\circ} \mathrm{C}$ and increased power yield to $2.96 \%$. Selimefendigil et al. [20] studied porous aluminum foams were applied as cooling fins. The foam thickness was variated from 6 to $10 \mathrm{~mm}$. The results showed that porous aluminum foams had reduced the PV temperature up to $1^{\circ} \mathrm{C}$ and the effect is not significant. Since the passive cooling technique showed promising findings, there is a strong need for further improvement under realistic conditions to bridge the gap between the research and industrial needs. The recent developments on PV cooling by the various authors with heat sinks are illustrated in Figure 1.

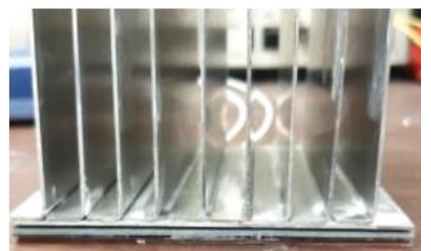

[12]
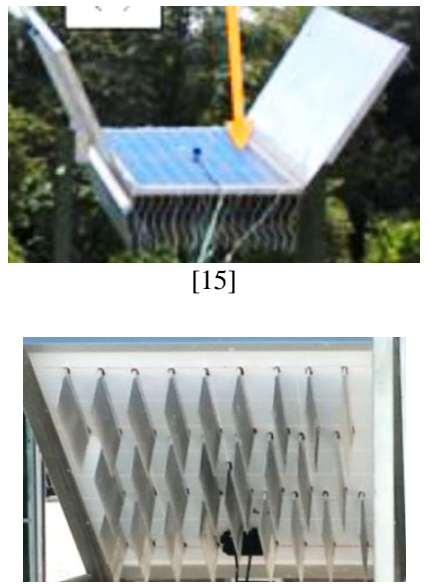

[18]

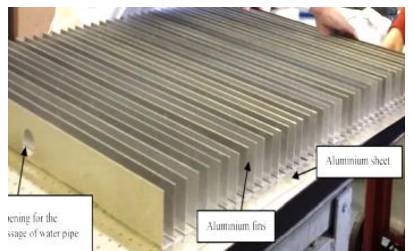

[13]
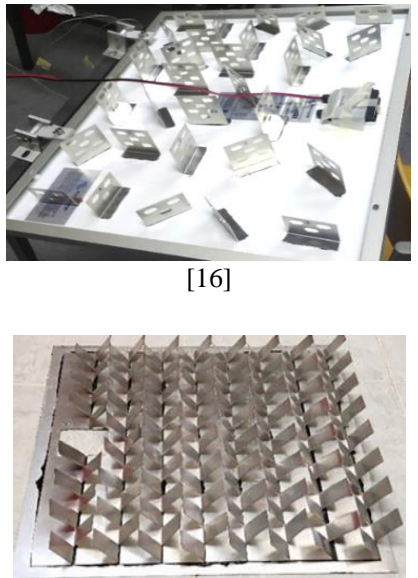

[19]

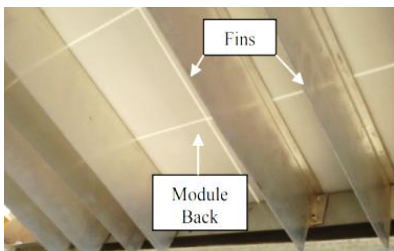

[14]

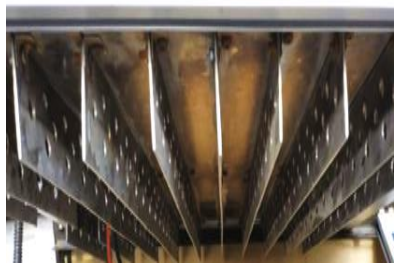

[17]

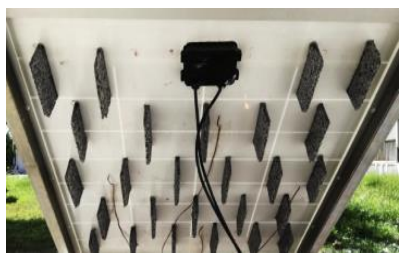

[20]

Figure 1. Recent developments of cooling heat sink for PV module

Since the output performances of PV modules are site-dependent, it is essential to investigate the influence of cooling heat sinks under outdoor testing conditions. Therefore, the proposed passive cooling technique under Malaysian climates was conducted by outdoor experimental means. The primary motivation of this study is to investigate the impact of cooling heat sinks on the electrical output performance of commercialized PV modules at a specific geographical condition. Thus, the findings of this study are proved 
reliable for improvement in temperature reduction using fin heat sinks. It allows stakeholders such as PV installers, PV plant owners, and other parties to favor an informed decision towards the heat sink cooling mechanism to enhance the PV system performance.

\section{METHODOLOGY}

The electrical output performance of a PV module is highly site-dependent, but the rated nominal power is based on the controlled environments known as standard test conditions. Various methods have been proposed to determine the module efficiency through simplified working equations [21]-[24]. However, the following equation is widely used to determine the PV module efficiency described as follows (1) [25].

$$
\eta=\eta_{S T C}\left[1-\beta\left(T_{P V}-T_{S T C}\right)\right]+\gamma \log G
$$

$\eta_{S T C}$ is the efficiency of a PV module at $=T_{S T C}\left(25^{\circ} \mathrm{C}\right), G$ is the irradiance level measured in $\mathrm{W} / \mathrm{m}^{2}$, and $T_{P V}$ is the PV module temperature. $\beta$ and $\gamma$ are the coefficients for the temperature and solar irradiance, respectively. The values for $\eta_{S T C}, \beta$, and $\gamma$ are given in the module datasheet. However, under real operating conditions (ROC), the power output of the PV modules installed at the test site differs from the power stated in the module datasheet. Several derating factors that need to be considered, known as power derating, $k_{\text {power derating }}$, and can be determined using (2) and (3) [26].

$$
\begin{aligned}
& P_{\text {roc }}=P_{S T C} \times k_{\text {power_derating }} \\
& k_{\text {power_derating }}=k_{\text {module_mismatch }} \times k_{\text {temp }} \times k_{g} \times k_{\text {dust }} \times k_{\text {aging }}
\end{aligned}
$$

Where $P_{\text {stc }}$ is the power rated at STC as per manufacturer's specification $\left(\mathrm{W}_{\mathrm{p}}\right), k_{\text {module_mismatch }}$ is the module mismatch derating factor, $k_{\text {temp }}$ is the module temperature derating factor, $k_{g}$ is the peak sun factor obtained by dividing the instantaneous irradiance with $1000 \mathrm{~W} / \mathrm{m}^{2}, k_{\text {dust }}$ is the dust effect derating factor, and $k_{\text {aging }}$ is the derating factor due to PV module's aging. In this study, $k_{\text {module_mismatch }}, k_{\text {dust }}$, and $k_{\text {aging }}$ parameters are constant $(=1.0)$ throughout the experiment and can be combined as $\alpha$. Therefore, the (2) becomes;

$$
P_{\text {roc }}=P_{S T C} \times k_{\text {temp }} \times k_{g} \times \alpha
$$

The values of $k_{\text {temp }}$ and $k_{g}$ can be estimated using [27]:

$$
\begin{aligned}
& k_{\text {temp }}=1+\left[\left(\frac{\gamma_{p m p}}{100 \%}\right) \times\left(T_{\text {module }}-T_{\text {STC }}\right)\right] \\
& k_{g}=\frac{\text { Solar irradiance }, G}{1000}
\end{aligned}
$$

where $\gamma_{p m p}$ is the module's temperature coefficient given in $\% /{ }^{\circ} \mathrm{C}$. The module temperature, $T_{\text {module }}$ is measured using K-type thermocouples positioned at the front and backside of PV modules. The $I V$ curve defines the performance of PV modules, which shows how the current varies as a function of the voltage. Based on the $I V$ curve, several parameters are used to characterize the electrical performance of the PV module, as presented in the fill factor (FF) in (7).

$$
F F=\frac{I_{m p} \times V_{m p}}{I_{s c} \times V_{o c}}
$$

Where $I_{m p}$ is current recorded at the maximum point of the IV curve, $I_{s c}$ is short-circuit current, $V_{m p}$ is the voltage at maximum power, and $V_{o c}$ is open-circuit voltage [27]. The $F F$ can be used to determine the efficiency of a PV module at specific irradiance and temperature. The expected yield can be defined as (8) [28].

$$
Y_{\text {exp }}=P_{S T C} \times P S H_{\text {poa }} \times k_{\text {total_deration }} \times \eta_{\text {sub_system }}
$$

PSHpoa is the peak sun hour (h), and $\eta_{\text {sub_system }}$ is the product of inverter and cable efficiency.

The test-rig setup was developed to evaluate the PV module performances under the local climate conditions of Malaysia $\left(2.1896^{\circ} \mathrm{N}, 102.2501^{\circ} \mathrm{E}\right)$. The main components for the experimental setup are the PV module, PV mounting structure, current-voltage tracer, and weather monitoring unit. The design consists of 
two identical monocrystalline PV modules $(120 \mathrm{Wp})$ and tilted at $18^{\circ}$ from the horizontal facing South to receive the maximum solar radiation. The fin geometry is illustrated in Figure 2 (a). One module was attached with the heat sinks for cooling (Panel A), while the other was used as a reference module (Panel B), as demonstrated in Figure 2 (b). The measures of incident solar irradiance shall comply with IEC 60904-3 [29]. Therefore, this work uses PV reference cells of the same glazing and technology for solar irradiance measurement with $\pm 0.2 \%$ sensitivity. All measurements were recorded every $2 \mathrm{~s}$ interval from 09:00 a.m to 05:00 p.m. The K-type thermocouples were used to measure the ambient temperature and the surface temperature of PV modules. The thermocouples were placed at several points at the front and rear side of PV modules having a sensitivity of $\pm 0.5 \%$ and the temperature range of $-200{ }^{\circ} \mathrm{C}$ to $+300{ }^{\circ} \mathrm{C}$. All temperature sensors were connected to the advanced data acquisition modules (ADAM 4018+), interfaced with the single RS-485 network.

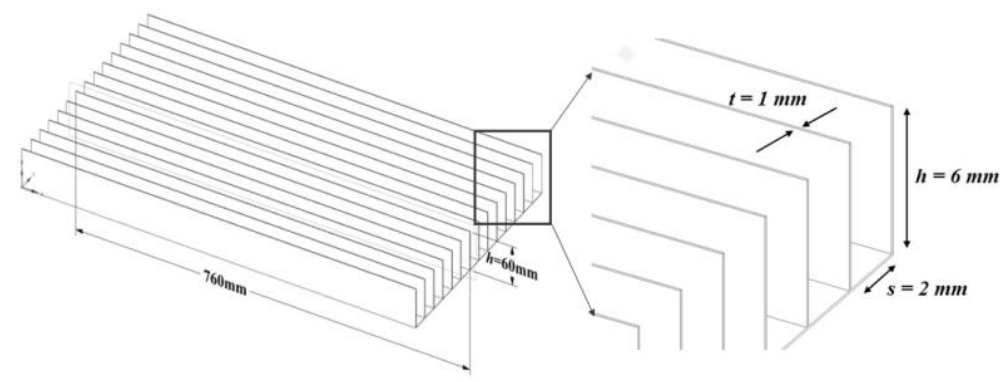

(a)

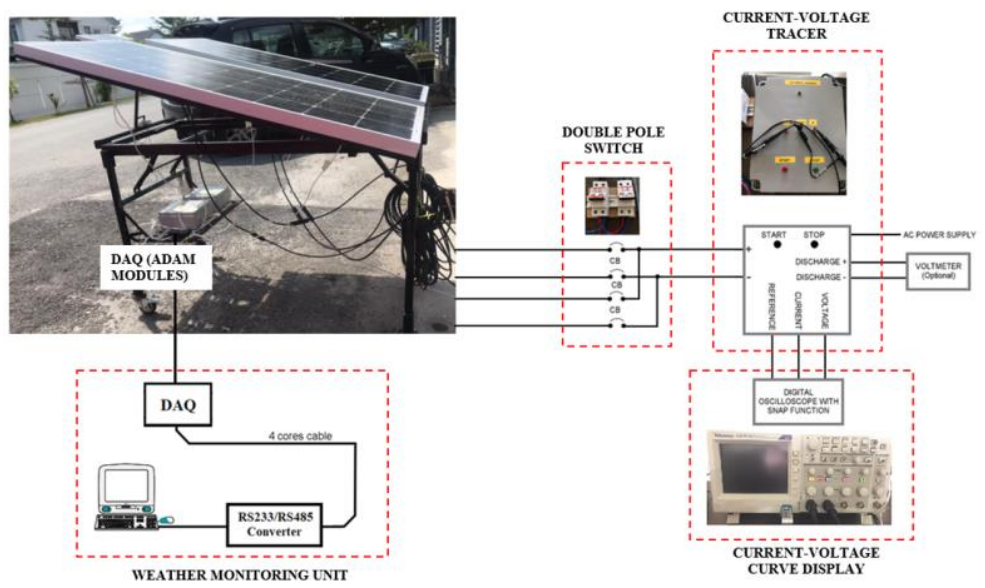

(b)

Figure 2. The detailed illustrations of (a) proposed fins geometry and (b) the experimental setup

\section{RESULTS AND DISCUSSION}

\subsection{The influence of fins heat sink on the $P V$ module temperature}

The two modules were installed to investigate comparatively the PV-Fin module with the conventional module. Although all the data was recorded for several days, the data is presented for the day with clear sky and stable solar irradiance on July 19, 2021. Solar irradiance, ambient temperature, and the surface temperature of PV modules were measured at the test site and presented in Figure 3 and Figure 4. Since Malaysia is located near the equator, the climate is hot and humid throughout the year. The recorded temperatures were high and stable between 26 to $37{ }^{\circ} \mathrm{C}$ throughout the day. It should be noted from the solar irradiance plot that cloudy conditions have occurred in the morning from 10:00 a.m. to 3:00 p.m., characterized by the dotted lines. The average highest and lowest solar irradiance values were recorded at 980 and $520 \mathrm{~W} / \mathrm{m}^{2}$, respectively.

As shown in Figure 4, the graph for the surface temperature of PV modules (with fins and without fins) is highly influenced by solar irradiance. The PV surface temperature plot is observed to have similar trends with the plot of solar irradiance. The surface temperature of the PV module with fins is lower than the surface temperature of the PV module without fins throughout the day. The maximum temperature difference between the two modules is $5.77^{\circ} \mathrm{C}$, and the average temperature difference is $3.25^{\circ} \mathrm{C}$. The surface temperature 
plot shows one peculiarity: The module with fin demonstrates a significant impact on the module temperature reduction at solar irradiance greater than $600 \mathrm{~W} / \mathrm{m}^{2}$. The surface temperature reduction was observed between 3.47 and $4.60{ }^{\circ} \mathrm{C}$. Meanwhile, the temperature reduction between both modules was insignificance as the weather got too cloudy, as shown in areas $\mathrm{X}$ and $\mathrm{Y}$. The temperature reduction drops between 1.29 to $1.5^{\circ} \mathrm{C}$. The temperature derating factor is an important parameter for assessing the PV module performance under long-term field exposure. Hence, the amount of $k_{\text {temp }}$ for both modules was determined based on (5). The lowest recorded $k_{\text {temp }}$ for PV with fins and PV without fins were 0.908 and 0.917 , respectively. Based on Figure 5, it can be concluded that fin heat sinks positively influenced the $k_{\text {temp }}$ by at least $3.4 \%$ throughout the day.

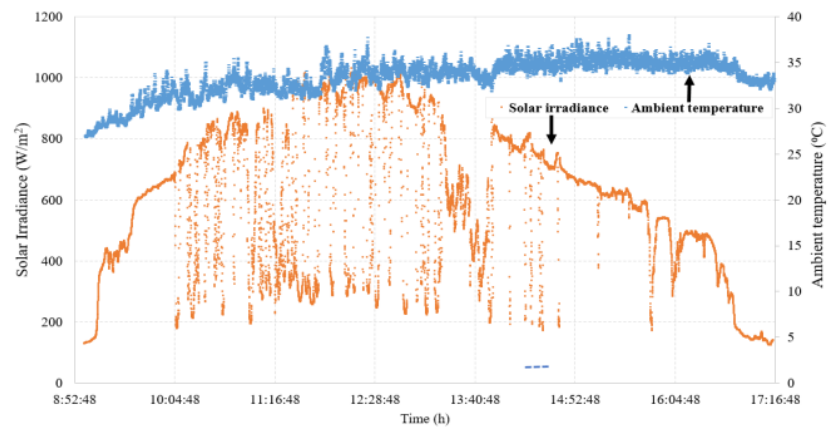

Figure 3. The weather data recorded every 2 s interval

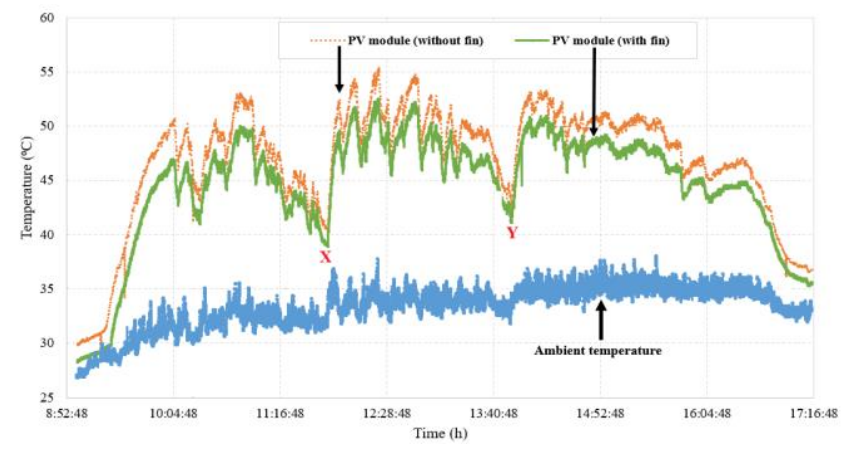

Figure 4. The surface temperature of PV modules

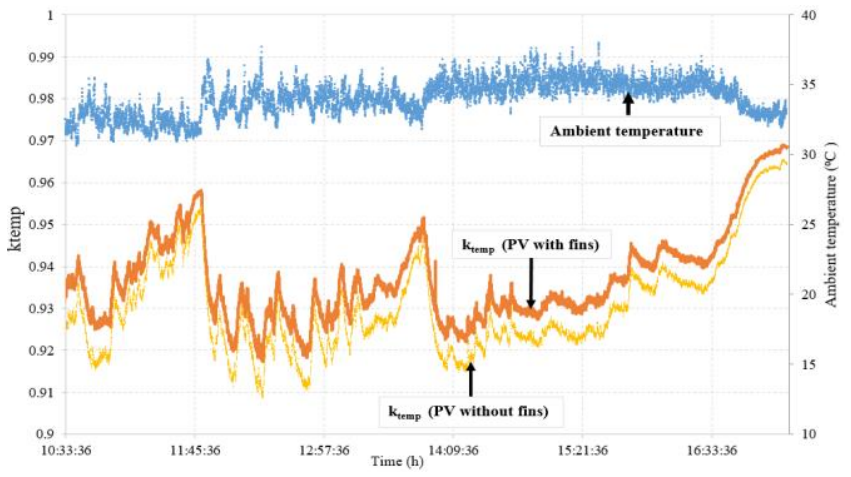

Figure 5. The influence of fins on the temperature derating factor, $k_{\text {temp }}$ of the PV module

\subsection{The influence of fins heat sink on the power output performance}

Temperature variation within the PV module significantly impacts the electrical output performance. Hence, the PV module performance is characterized by a current-voltage $(I-V)$ curve measured from the current-voltage tracer. The measurements were recorded every 1-hour intervals. The experimental results produce several important electrical parameters, including short-circuit current $\left(I_{\mathrm{sc}}\right)$, open-circuit voltage $\left(V_{o c}\right)$, 
current at maximum power $\left(I_{m p}\right)$, and voltage at maximum power $\left(V_{m p}\right)$. During these measurements, the minimum and maximum recorded solar irradiances were 520 and $980 \mathrm{~W} / \mathrm{m}^{2}$, respectively. It can be observed that the $V_{o c}$ for the PV module with fins is higher than the reference module by at least $3.14 \%$ (see Figure 6). However, Figure 7 shows the power curves for both PV modules tested under outdoor operating conditions. Since solar cells are made up of semiconductor materials, the increase in temperature excites excess electrons and holes, causing the greater depletion region width known as the charge separation layer [30]. Hence, the $V_{\mathrm{oc}}$ is very much dependent on the temperature. Besides, the value of $V_{m p}$ had increased from $17.2 \mathrm{~V}$ to $20.4 \mathrm{~V}$ when using fins. Consequently, the fill factor (FF) values had improved from 0.744 to 0.826 .

The recorded $I_{s c}$ for the PV module with fins and without fins was 6.08 A and 6.10 A, respectively. The change of $\mathrm{I}_{\mathrm{sc}}$ with temperature highly depends on the light trapping properties of the designed solar cell. Hence, it can be observed that the change in $I_{\mathrm{sc}}$ is much smaller than the $V_{O C}$. The overall electrical performances for tested PV modules are summarized in Table 1. It is worth noting that when the module temperature drops, the voltage rises, resulting in a substantial increase in available maximum electrical power despite a slight decrease in short-circuit current. The average power output is improved by $14.2 \%$ when using fin heat sinks as the cooling approach, as shown in Figure 8.

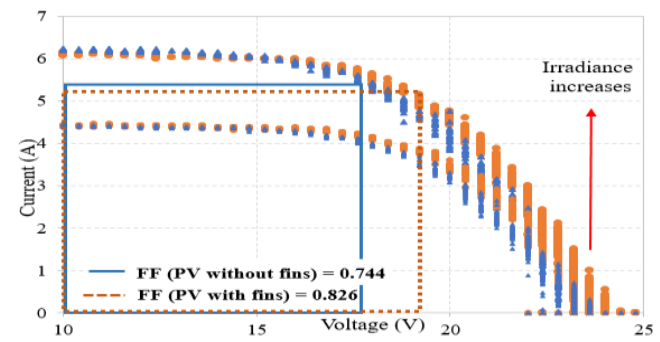

Figure 6. Current-Voltage curves

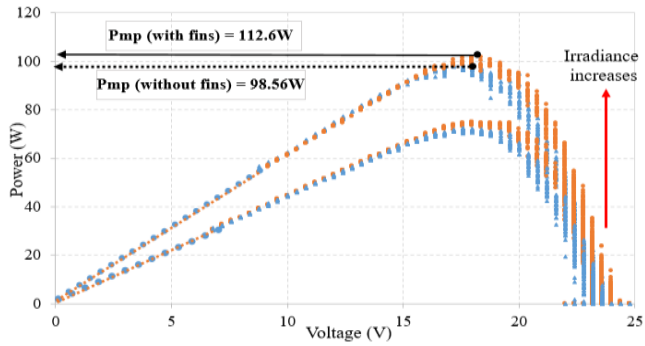

Figure 7. Power curves

Table 1. The overall electrical performances under outdoor testing conditions

\begin{tabular}{|c|c|c|}
\hline \multirow{2}{*}{ Electrical parameters } & \multicolumn{2}{|c|}{ Measured data at an irradiance of $980 \mathrm{~W} / \mathrm{m}^{2}$ and ambient temperature of $34.11^{\circ} \mathrm{C}$} \\
\hline & PV without fins & PV with fins \\
\hline Short-circuit current, $\mathrm{I}_{\mathrm{sc}}$ & $6.10 \mathrm{~A}$ & $6.08 \mathrm{~A}$ \\
\hline Open-circuit voltage, $\mathrm{V}_{\mathrm{oc}}$ & $21.2 \mathrm{~V}$ & $22.4 \mathrm{~V}$ \\
\hline Current at the maximum point, $\mathrm{I}_{\mathrm{mp}}$ & $5.6 \mathrm{~A}$ & $5.52 \mathrm{~A}$ \\
\hline Voltage at the maximum point, $\mathrm{V}_{\mathrm{mp}}$ & $17.1 \mathrm{~V}$ & $20.4 \mathrm{~V}$ \\
\hline Maximum power output, $\mathrm{P}_{\mathrm{mp}}$ & $98.56 \mathrm{~W}$ & $112.6 \mathrm{~W}$ \\
\hline Fill factor, FF & 0.744 & 0.826 \\
\hline
\end{tabular}

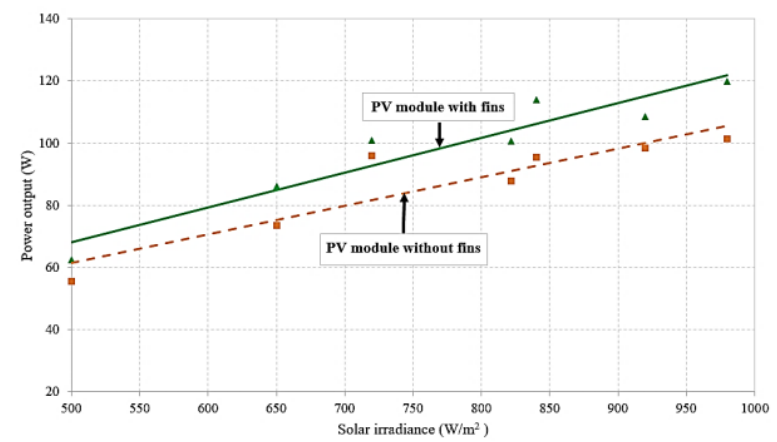

Figure 8 . The impact of power output under varying solar irradiances

\section{CONCLUSION}

This work reports the experimental findings on the passively cooled PV modules using rectangular fin heat sinks under outdoor testing conditions. It can be concluded that the proposed cooling approach results in a $3.25{ }^{\circ} \mathrm{C}$ average reduction in the PV module temperature. Thus, the maximum electrical power output increases up to $14.2 \%$ by integrating the fin heat sink at the backside of the PV module. It was found that the heat sink effect on the PV module performance is significant at high solar irradiance than low solar irradiance. The finding suggests the feasibility of implementing the heat sink as a cooling approach in countries near the equator. 


\section{ACKNOWLEDGEMENTS}

The authors would like to acknowledge the Universiti Kebangsaan Malaysia (UKM) for supporting this research through research funding FRGS/1/2019/TK07/UKM/02/4 (Fundamental Research Grant Scheme), the Ministry of Higher Education Malaysia, and Universiti Teknikal Malaysia Melaka (UTeM) for some of the equipment used in the experiment.

\section{REFERENCES}

[1] M. A. Green, "Photovoltaic technology and visions for the future," Prog. Energy, 2019, doi: 10.1088/2516-1083/ab0fa8

[2] I. Marinić-Kragić, S. Nižetić, F. Grubišić-Čabo, and D. Čoko, "Analysis and optimization of passive cooling approach for freestanding photovoltaic panel: Introduction of slits," Energy Convers. Manag., 2019, doi: 10.1016/j.enconman.2019.112277.

[3] E. Z. Ahmad, A. Fazlizan, H. Jarimi, K. Sopian, and A. Ibrahim, "Enhanced heat dissipation of truncated multi-level fin heat sink (MLFHS ) in case of natural convection for photovoltaic cooling," Case Stud. Therm. Eng., vol. 28, p. 101578, 2021, doi: 10.1016/j.csite.2021.101578.

[4] H. A. Kazem, M. T. Chaichan, A. H. A. Al-Waeli, and K. Sopian, "A review of dust accumulation and cleaning methods for solar photovoltaic systems," J. Clean. Prod., vol. 276, p. 123187, 2020, doi: 10.1016/j.jclepro.2020.123187.

[5] J. Siecker, K. Kusakana, and B. P. Numbi, "A review of solar photovoltaic systems cooling technologies," Renewable and Sustainable Energy Reviews. pp. 192-203, vol. 79, 2017, doi: 10.1016/j.rser.2017.05.053.

[6] S. Nižetić, M. Jurcevic, D. Coko, and M. Arıcı, "A novel and effective passive cooling strategy for photovoltaic panel," Renew. Sustain. Energy Rev., vol. 145, no. March, 2021, doi: 10.1016/j.rser.2021.111164.

[7] S. Nižetić, E. Giama, and A. M. Papadopoulos, "Comprehensive analysis and general economic-environmental evaluation of cooling techniques for photovoltaic panels, Part II: Active cooling techniques," Energy Convers. Manag., vol. 155, no. October 2017, pp. 301-323, 2018, doi: 10.1016/j.enconman.2017.10.071.

[8] M. N. Kamarudin, S. Rozali, and M. S. Jamri, “Active cooling photovoltaic with IoT facility," Int. J. Power Electron. Drive Syst., vol. 12, no. 3, pp. 1494-1504, 2021, doi: 10.11591/ijpeds.v12.i3.

[9] A. Fudholi, M. Zohri, I. Taslim, M. A. Indrianti, and I. N. Manyoe, "Theoretical approach model of building integrated photovoltaic thermal air collector," Int. J. Power Electron. Drive Syst., vol. 11, no. 2, pp. 1002-1010, 2020, doi: 10.11591/ijpeds.v11.i2.pp10021010 .

[10] I. M. Saadon, H. Windiarti, M. N. Othman, E. Z. Ahmad, and K. A. M. Annuar, "River Debris Management System using Off-Grid Photovoltaic Module," in MATEC Web of Conferences, 2017, vol. 97, doi: 10.1051/matecconf/20179701070.

[11] N. H. Miswan, N. H. Hussin, R. M. Said, K. Hamzah, and E. Z. Ahmad, "ARAR algorithm in forecasting electricity load demand in Malaysia," Glob. J. Pure Appl. Math., vol. 12, no. 1, 2016.

[12] E. Johnston, P. S. B. Szabo, and N. S. Bennett, "Cooling silicon photovoltaic cells using finned heat sinks and the effect of inclination angle,” Therm. Sci. Eng. Prog., vol. 23, no. March, p. 100902, 2021, doi: 10.1016/j.tsep.2021.100902.

[13] L. Idoko, O. Anaya-Lara, and A. McDonald, "Enhancing PV modules efficiency and power output using multi-concept cooling technique," Energy Reports, vol. 4, pp. 357-369, 2018, doi: 10.1016/j.egyr.2018.05.004.

[14] A. A. raheim Amr, A. A. M. Hassan, M. Abdel-Salam, and A. H. M. El-Sayed, "Enhancement of photovoltaic system performance via passive cooling: Theory versus experiment," Renewable Energy. 2019, doi: 10.1016/j.renene.2019.03.048.

[15] A. M. Elbreki, K. Sopian, A. Fazlizan, and A. Ibrahim, "Case Studies in Thermal Engineering An innovative technique of passive cooling PV module using lapping fins and planner reflector," Case Stud. Therm. Eng., vol. 19, no. January, p. 100607, 2020, doi: 10.1016/j.csite.2020.100607.

[16] F. Grubišić-Čabo, S. Nižetić, D. Čoko, I. Marinić Kragić, and A. Papadopoulos, "Experimental investigation of the passive cooled free-standing photovoltaic panel with fixed aluminum fins on the backside surface," J. Clean. Prod., vol. 176, pp. 119-129, 2018, doi: 10.1016/j.jclepro.2017.12.149.

[17] Z. Arifin, D. D. D. P. Tjahjana, S. Hadi, R. A. Rachmanto, G. Setyohandoko, and B. Sutanto, "Numerical and experimental investigation of air cooling for photovoltaic panels using aluminum heat sinks," Int. J. Photoenergy, vol. 2020, 2020, doi: $10.1155 / 2020 / 1574274$

[18] F. Bayrak, H. F. Oztop, and F. Selimefendigil, "Effects of different fin parameters on temperature and efficiency for cooling of photovoltaic panels under natural convection," Sol. Energy, vol. 188, no. June, pp. 484-494, 2019, doi: 10.1016/j.solener.2019.06.036.

[19] J. G. Hernandez-Perez, J. G. Carrillo, A. Bassam, M. Flota-Banuelos, and L. D. Patino-Lopez, "Thermal performance of a discontinuous finned heatsink profile for PV passive cooling," Appl. Therm. Eng., no. April, p. 116238, 2020, doi: 10.1016/j.applthermaleng.2020.116238.

[20] F. Selimefendigil, F. Bayrak, and H. F. Oztop, "Experimental analysis and dynamic modeling of a photovoltaic module with porous fi ns," Renew. Energy, vol. 125, pp. 193-205, 2018, doi: 10.1016/j.renene.2018.02.002.

[21] M. Mittal, B. Bora, S. Saxena, and A. M. Gaur, "Performance prediction of PV module using electrical equivalent model and artificial neural network," Sol. Energy, vol. 176, no. October, pp. 104-117, 2018, doi: 10.1016/j.solener.2018.10.018.

[22] A. M. Muzathik, "Photovoltaic Modules Operating Temperature Estimation Using a Simple Correlation," International Journal of Energy Engineering, vol. 4, pp. 151-158, 2014

[23] H. Zainuddin, S. Shaari, A. M. Omar, S. I. Sulaiman, Z. Mahmud, and F. Muhamad Darus, "Prediction of module operating temperatures for free-standing (FS) photovoltaic (PV) system in Malaysia," Int. Rev. Model. Simulations, 2011.

[24] A. S. A. Hamid, A. Ibrahim, J. Assadeg, E. Z. Ahmad, and K. Sopian, "Techno-economic Analysis of a Hybrid Solar Dryer with a Vacuum Tube Collector for Hibiscus Cannabinus L Fiber,” Int. J. Renew. Energy Res., vol. 10, no. 4, pp. 1609-1613, 2020.

[25] A. Pavgi, J. Oh, J. Kuitche, S. Tatapudi, and G. Tamizhmani, "Thermal Uniformity Mapping of PV Modules and Plants," 2017 IEEE 44th Photovoltaic Specialist Conference (PVSC), 2017, pp. 1877-1882, doi: 10.1109/PVSC.2017.8366308.

[26] A. M. Omar and S. Shaari, "Sizing verification of photovoltaic array and grid-connected inverter ratio for the Malaysian building integrated photovoltaic project," Int. J. Low-Carbon Technol., vol. 4, no. 4, pp. 254-257, 2009, doi: 10.1093/ijlct/ctp033.

[27] S. N. Geoff Stapleton, Grid-connected Solar Electric Systems: The Earthscan Expert Handbook for Planning, Design and Installation, vol. 1. Routledge, 2012.

[28] E. Z. Ahmad et al., "Recent advances in passive cooling methods for photovoltaic performance enhancement," Int. J. Electr. Comput. Eng., vol. 11, no. 1, pp. 146-154, 2021, doi: 10.11591/ijece.v11i1.pp146-154.

[29] L. Dunn, M. Gostein, and K. Emery, "Comparison of pyranometers vs. PV reference cells for evaluation of PV array performance," 
Conf. Rec. IEEE Photovolt. Spec. Conf., pp. 2899-2904, 2012, doi: 10.1109/PVSC.2012.6318193.

[30] M. Al-Chaderchi, K. Sopian, T. Salameh, D. Zhang, and M. A. Alghoul, "Enhancing the Performance of PV Panel Undergoing Shading Effects," Int. J. Power Electron. Drive Syst., vol. 9, no. 4, p. 1937, 2018, doi: 10.11591/ijpeds.v9.i4.pp1937-1943.

\section{BIOGRAPHIES OF AUTHORS}

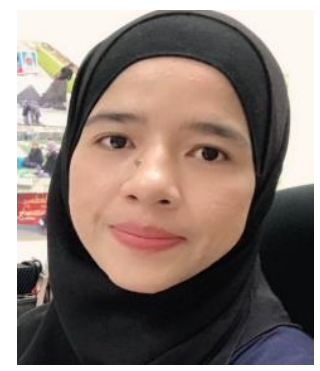

Emy Zairah Ahmad (D) 8d SC P graduated with MEng in Electrical Engineering from The University of Sheffield, UK, in 2009 and the MSc from TU Berlin, Germany, in 2012. Her research areas include solar photovoltaic and energy efficiency. She can be contacted at email: emyzairah@utem.edu.my.

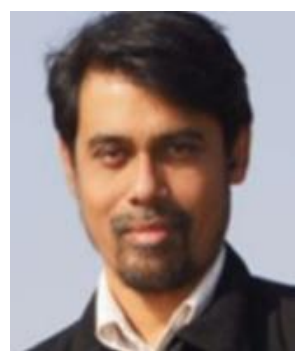

Kamaruzzaman Sopian (iD) 8d SC P graduated with the BS Mechanical Engineering from the University of Wisconsin-Madison in 1985, the MS in the Energy Resources University of Pittsburgh in 1989, and Ph.D. in Mechanical Engineering from the Dorgan Solar Laboratory, the University of Miami at Coral Gables in 1997. He has been involved in renewable energy for more than 25-years. He can be contacted at email: ksopian@ukm.edu.my.

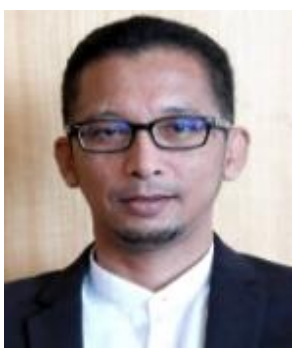

Adnan Ibrahim (iD 8d SC P holds a Degree (Hons) in Manufacturing Systems Engineering from the University of Portsmouth, the United Kingdom in 2000, Master of Science in Integrated Product Development from University of Strathclyde, the United Kingdom in 2002 and Doctor of Philosophy in Renewable Energy from Universiti Kebangsaan Malaysia in 2012. He can be contacted at email: iadnan@ukm.edu.my.

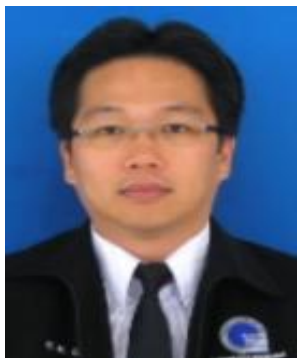

Chin Kim Gan (D) 81 SC P received his B.Eng. and M.Sc. degrees in electrical engineering from the Universiti Teknologi Malaysia (UTM) and PhD degree from the Imperial College London, UK. He is currently a Senior Lecturer at the Universiti Teknikal Malaysia Melaka (UTeM). His research interests are distribution network design, renewable energy, and smart grid integration. He can be contacted at email:ckgan@utem.edu.my.

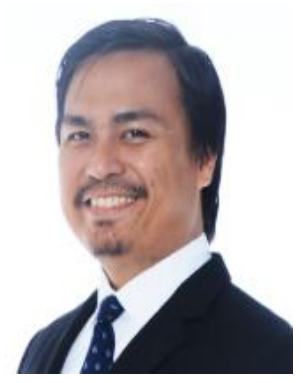

Mohd Suffian Ab Razak (D) 8 SC P graduated with the BEng in Mechanical Engineering from Kobe University, Japan, in 2008, the MEng in Mechanical Engineering from Universiti Malaya, Malaysia. Previous experience working with Malaysia National carmaker, PROTON, stimulates his passion for heat transfer and structural design optimization. He can be contacted at email:suffian@utem.edu.my. 